\title{
Tourism Marketing: Measuring Tourist Satisfaction
}

\author{
Juan Carlos Castro¹, Mauricio Quisimalin ${ }^{1}$, Carmen de Pablos ${ }^{2}$, Viviana Gancino ${ }^{1}$, Jessica Jerez ${ }^{1}$
}

${ }^{1}$ Marketing Department, Universidad Técnica de Ambato, Ambato, Ecuador

${ }^{2}$ Legal and Social Sciences Department, Universidad Rey Juan Carlos, Madrid, España

Email: juanccastro@uta.edu.ec, hernanmquisimalin@uta.edu.ec,carmen.depablos@urjc.es,

viviana.gancino.uta@gmail.com, jessica.jerez.uta@gmail.com

How to cite this paper: Castro, J.C., Quisimalin, M., de Pablos, C., Gancino, V. and Jerez, J. (2017) Tourism Marketing: Measuring Tourist Satisfaction. Journal of Service Science and Management, 10, 280-308. https://doi.org/10.4236/jssm.2017.103023

Received: April 4, 2017

Accepted: June 20, 2017

Published: June 23, 2017

Copyright $\odot 2017$ by authors and Scientific Research Publishing Inc. This work is licensed under the Creative Commons Attribution International License (CC BY 4.0).

http://creativecommons.org/licenses/by/4.0/

\begin{abstract}
The research was aimed at identifying and validating determinants of tourist satisfaction. The study area was the provinces of Chimborazo, Cotopaxi, Pastaza, Tungurahua, defined in Zone 3 of Ecuador, which transcended their geostrategic commercial position in the center of the country. In this context, the main objective of the study was to measure tourist satisfaction and to evaluate its determinants defined in variables such as product, price, distribution and tourist service as secondary axes of scope and transversal design. The sample synthesized an unknown sampling frame of 610 random tourists, representative sample where a semi-structured personal survey of 34 questions was applied considering 46 moderate variables and 9 classification variables. The statistical techniques used correspond to the partial least squares (PLS) method to give consistency to four items of product, two of the price, three of the distribution, one of the promotion and finally five of the service that allowed. All this was validated with the internal consistency of the model through composite relativity (CR), and Cron Bach's alpha, convergent validity was analyzed using the mean variance extracted (AVE), the structural model was examined through the coefficient Of determination (R2) and the Path ( $\beta$ ) values, determined that this relationship is positive and consistent between variables of infrastructure, attention, cleanliness of the establishment and availability of parking; food and fun; ease of finding places and availability of service information; gastronomic and cultural tourism, positive tourism experience, successful choice of destination, fulfilled expectations, repetition of the trip and recommendation of destination.
\end{abstract}

\section{Keywords}

Tourist Satisfaction, Product, Price, Distribution, Promotion and Touristic Service 


\section{Introduction}

Tourism as an industry has grown significantly in recent times and has allowed for short-term voluntary movements of people (tourists and visitors) outside their home; this has generated sources of employment, and has allowed foreign exchange to help development and welfare for the country receiving tourism [1] [2] [3]. The cities aim to make investments to generate actions that promote culture, infrastructure, government policy, technology and research and professionalization aimed at achieving the development of this activity [4] [5] to generate value and promote the satisfaction of visitors and the development of destinations.

People who visit a tourist destination expect their stay to be unique and enjoyable, therefore, it is of great importance to study the tourist market, as a growing economic activity and necessary to explore the needs of visitors and their degree of satisfaction [6], from the quality of the destinations that make the difference and capture the fidelity of the visitors; under this premise, [7] propose to measure the satisfaction of the tourists through the service, perceived quality and expectation.

The image of the destination and the perception of the image of the visitors is constituted in the brand value of a destination, and becomes an axis of development, in the economic and marketing part, the latter generates a value in the minds of the Tourists, translated in the interest for the tourist demand that have led to conduct several studies that have led to the development of behavioral models [8] [9] [10], of the tourist and the selection of the place that visits, landing in factors of study as: needs, motivation, perception, attitude, personality, image. Social factors: lifestyle, family life cycle, family, social class; situational factors: opinions, physical and social environment, time, mood. Psychological factors: prestige, escape; physical factors: rest, fitness, health treatment; demographic factors: age, income, education, marital status, beliefs, [11] managing to define different segments: a) tourists interested in leisure, holidays and culture; b) interested in the environment and nature; c) tourists interested in the value of money.

Therefore, the satisfaction of the trip is essential in the success of a tourist business and the comparison between the expectation and the experience must be constantly checked during the evaluation of the visitor to the destination with respect to the quality of the service perceived in the trip. In many cases, tourism satisfaction and perceived quality have much in common, since the quality of the service is evaluated by visitors according to factors such as comfort, friendliness, security, cleanliness, accommodation, transportation and infrastructure [12] in three periods in the tourism sector: 1) impact; 2) regression; 3) recovery [13][19].

This article shows the value of the research, which is linked to the purpose of the study, which seeks to analyze the determinants of tourist satisfaction in zone three of Ecuador, which includes the provinces of Chimborazo, Cotopaxi, Pastaza and Tungurahua, where the question of research was designed from a her- 
meneutical-historical research perspective. What are the most significant determinants of the market tourism that are related to tourist satisfaction? This allowed to define seven theoretical constructions: tourist product, tourist price, tourist distribution, tourist promotion, tourist services, tourist profile and tourist satisfaction.

With the exposition of the factors we defined the starting hypotheses to provide direction and direction to the research, this allowed to articulate aspects of reality through the generation of scenarios hypothetical where the network of relationships around each category and descriptive arguments aimed at the reconstruction of relevant aspects of tourist satisfaction.

\section{Hypothesis of departure}

The service includes the emotions of tourists because their great majority is based on experiences and satisfaction [20]. The services offered to satisfy the needs of the tourist are related by the infrastructure, attention, cleanliness of the establishment, availability of parking lots is constituted in positive elements that strengthen the tourist efficiency of the destination, and promote an experience that allows the decision of return [15] [21] [22]. The service rendering process gives rise to key assessments in tourist satisfaction because loyal customers play an important current and future value that benefits the company and its competitiveness [23]. To observe in the model of structural equations SERVQUAL analyzed by [24], which focuses on determining that service quality is an antecedent of consumer satisfaction. On the basis of these precepts the hypothesis is posed:

H1: Tourist services in destinations have a positive influence on tourist satisfaction.

The perception of tourists in the provision of payment for food services and entertainment activities for [25] should be moderate, considering that the price of food and beverages reflects the quality of products, services and food dishes presented at the destination, this makes the characteristics of a destination differentiate with another, and can define a relation quality/price, [26]. Therefore, leisure activities are defined by tourists as the development of a pleasant activity of quality as part of their motivating experiences and their price relationship linked to the planned cost margin, in the value of the service and the experience, which has been perceived in the destination as part of their satisfaction, [27]. In this sense, the second hypothesis arises:

H2: The price of the touristic product is an element that determines the Satisfaction of the Tourist.

Access to services and tourist sites, are requirements that visitors value when planning their trip, that is, information allows tourists to have knowledge of safe activities and sites that can be visited [28]. Therefore, when the tourist plans his trip with truthful and timely information, he is ready to approach the destination to learn about entertainment, leisure activities, restaurants and hotels [29]. Thus, tourism services and places are considered as productive chains within the tourism sector, encompassing hotels, travel agencies, means of transport, res- 
taurants, with the intention of satisfying the needs that tourists demand during their stay at the destination [30]. On the basis of these considerations the third hypothesis is raised:

H3: The perception of logistics at the destination is directly associated with the tourist satisfaction.

The promotion as a strategic element of communication allows highlighting the tourist potential of a territory, through various campaigns in conventional and non-conventional media, revealing the natural attractions that under the perception of visitors constitute guarantees of quality and image of brand [31], translated into benefits and led to the satisfaction of the visitor under the premise of investment of specific assets that the tourist perceives in the destination [32].

Therefore, boosting the attractions and tourism activities of the destination according to the types of tourism generates comparative and competitive advantages that promotes market opportunities and impels the tourist to generate unique experiences that are constituted; in covered needs considering different tastes and preferences or activities that can develop such as: adventure tourism, cultural tourism, gastronomic tourism, health tourism [15] [33] [34] [35] [36] [37]. Underlying these premises, the fourth hypothesis arises:

H4: Touristic promotion of a destination positively influences Tourist Satisfaction.

Tourism trends, considering elements that generate value in travel and tourist satisfaction include the choice of place to visit, expectations, consumption experiences, recommendation and repetition of the trip. Therefore, the destination, its characteristics and the factors that drive the demand become the determinants of choice, giving rise to the comparison between tourist destinations that will ultimately determine tourist satisfaction or dissatisfaction [38].

The perceptions of the tourist are valued in relation to expectations, in this sense, the quality of services is evaluated periodically to examine their satisfaction in the destination [18]. That is, tourists with the experiences generated from visits generate higher expectations that may interfere with their satisfaction [39].

Therefore, the perceived quality can generate direct effects on the positive experience in the tourist [40] since the more positive experiences developed in the destination, the tourist tends to stay longer in relation to another destination [21]. Therefore, the image and the value of the destination stimulate the satisfaction of the tourists and their loyalty, which is triggered in the recommendation of the destination according to the expectations of the visitor [34] [41] [42]. According to these considerations, the fifth hypothesis is posed:

H5: The value that the tourist gives to the trip is intensely related to general satisfaction.

Tourists are heterogeneous in their perception of destiny, by their characteristics and attributes, as well as by the income and occupation which interferes with their behavior [43]. Characteristics such as the economic income intrinsically linked to the occupation generate the type of vacation that the tourist wishes to 
experience during their stay, which are linked to having new experiences [44]. Thus, the economic aspect is a resource that allows determining the estimated time and necessary expenses that can be realized in the purchase of tourism products or services at the destination [45]. In this sense, the sixth hypothesis is proposed:

H6: The characteristics and attributes of tourists are strongly associated with their destination satisfaction.

\section{Methodology}

This research promotes the measurement of tourist satisfaction [46]. In the first stage, a systematic process of information search was carried out in databases of scientific relevance research, proquest, scielo, science direct, scopus, springer, gale cengage learning. Tourism-oriented publications and tourist satisfaction were selected and a list of terms and keywords used by the authors on a recurrent basis (common to most and frequently mentioned by all) was identified. This technique addressed the first units or conceptual ideas that were designed in the software Atlas, with qualitative analysis capabilities.

\subsection{Content Validity}

With the basis of qualitative order, items were formulated that allowed to explore the measurement of tourist satisfaction, under three proposals [47]. An open informal interview (qualitative validation instrument) was developed to obtain the criteria of judges, experts and part of the tourist population, to strengthen the meta-analysis constructed with the systematic information of scientific publications. For the selection of judges and experts the following equation was determined:

$$
n=e(1-e) K / i^{2}, n=(0.03(1-0.03) 4) / 0.11^{2}
$$

where in $\mathrm{n}=10 ; 10$ judges and 10 tourism experts were interviewed; to have an approach to the tourist population is based on data released by the World Tourism Organization (WTO), which registers 1,133 million tourists who traveled to Ecuador in 2013 and in 2014 and there is an increase of 4.3\%, obtaining 1181 million tourists who visited Ecuador, contrasted with data from the Ministry of Tourism where it is pointed out that $14.79 \%$ of visits are destined for Tungurahua Province, that is, 174,669 tourists visited this province in 2014. With the analysis of Data, was projected to 2015 with a growth rate of $1.54 \%$ and it was determined that 177,358 tourists who would visit the Province, a reference that allowed to apply the instrument of qualitative order to tourists and its calculation was made through of the equation:

$$
n=\left(N \sigma^{2} Z^{2}\right) /\left((N-1) e^{2}+\sigma^{2} Z^{2}\right)
$$

therefore

$$
n=\left(177358 \times 0.5^{2} \times 1.96^{2}\right) /\left((177358-1) \times 0.05^{2}+0.5^{2} \times 1.96^{2}\right)
$$

$\sigma=$ desviation of $0.5 ; Z=95 \%$ confidence level equivalent to $1.96 ; E=$ acceptable limit of error of $0.05 \%$ obtaining 383 tourists as a population sample, 
under these circumstances 10\% (38 unstructured interviews) were taken, results that allowed quantifying and synthesizing the relevance of the factors proposed to define the elements of Study of the satisfaction of the tourist managing to generate the pertinence and validity of content with the theoretical evidence, the criterion of judges, experts and the tourist population that visits the destination.

\subsection{Operationalization of the Variable}

The transition of the variable to the item [48] allowed the development of indicators and items for each variable that was intended to be measured, using a proposed model based on meta-analysis, interviews with judges, experts, population, and the theoretical perspective that allowed the modification, inclusion and improvement of the dimensions, variables, indicators and the writing of the items, landing in the conceptual and operational operationalization, which gave way to the first draft of the documentary instrument (survey), with a total of one hundred and three items grouped into six dimensions (profile, product, price, distribution, promotion, and the tourist satisfaction study variable).

Once the six dimensions were defined, the sample size was calculated for the estimation of frequencies with an unknown sampling frame, since there was no record or database of tourists visiting zone 3 , considering Formula

$$
n=\left(Z_{1-\alpha / 2}^{2} * p * q\right) / d^{2}
$$

where alpha $(\alpha)=5 \%$ was assigned; Confidence level $1-0.050 / 2=0.975 ; Z$ of $(1$ $-\alpha / 2)=1.960$; Prevalence $(p)=0.50$; Complement of $p(q)=0.50$; Precision $(d)$ $=4 \%$, obtaining $n=610$ tourists to survey in Zone 3 (Tungurahua, Cotopaxi, Chimborazo, Pastaza). For the application of the instrument was considered the most visited places by tourists; a competitive advantage matrix was developed, based on eight criteria: 1) number of tourists visiting each province and canton; 2) number of tourist attractions; 3) accommodation services; 4) food and beverage services; 5) intermediation services, tourist services agency and event organizers, congresses; 6) operating services when travel agencies provide their own transportation considered as part of the agency; 7) spa services, bowling alleys, skating rinks, racecourse and recreation centers; 8) tourist transport.

Under these circumstances, the pilot test was carried out on 61 tourists $(10 \%$ of the total sample), in the cantons of the province according to the highest scores of the competitive advantage matrix, whose destinations were favorable to compile the information of each province, as shown in Table 1.

The development of the survey was determined by a structured questionnaire that was applied personally to tourists [49] or units of analysis [50]. The construction of the instrument had nuances of improvement, grouping and discrimination of items. In the first stage of construction, the instrument consisted of 103 items, in a second stage under an exhaustive review items were unified and excluded, contracting to 58 items. Finally, a third stage under a review and discriminant analysis of items for the value and utility of information that was given according to the conceptual composition and operational scope resulted in 44 items for the pilot survey that was applied to 61 tourists [51]. This allowed for 
Table 1. Calculation of the sample according to the competitive advantage of each province.

\begin{tabular}{cccccc}
\hline \multirow{2}{*}{ State } & City & $\begin{array}{c}\text { Matrix Score } \\
\text { Competitive } \\
\text { Advantage }\end{array}$ & $\begin{array}{c}\text { Proportion } \\
\text { to } \mathbf{1 0 0 \%}\end{array}$ & $\begin{array}{c}\text { Number } \\
\text { of tourists }\end{array}$ & $\begin{array}{c}\text { Pilot } \\
\text { test }\end{array}$ \\
\hline \multirow{2}{*}{ Tungurahua } & Ambato & 3.289 & 46.94 & 145 & 15 \\
& Baños & 3.718 & 53.06 & 164 & 16 \\
Cotopaxi & Total Tungurahua & 4 & 50.79 & 310 & 31 \\
Chimborazo & Latacunga & 1.375 & 17.46 & 107 & 11 \\
Pastaza & Riobamba & 1.750 & 22.22 & 136 & 14 \\
& Puyo & 0.75 & 9.52 & 58 & 5 \\
\hline
\end{tabular}

Note: Own elaboration.

a quantitative analysis, and evidence was found that made it difficult to understand some items and their way of measuring tourist satisfaction.

Table 2 shows the first phase of construction of the instrument. A total of 103 items were grouped into ten dimensions: tourist profile, product, price, distribution, promotion, tourist services, tourism, management, competitiveness and tourist satisfaction.

Table 3 shows the second phase, several items were unified by the similarity of scales, including items by their degree of importance; these changes were performed for the first pilot test for 61 tourists, with 55 items, to verify the comprehension and importance of measuring the latent variable "tourist satisfaction".

Table 4 shows that, when the first pilot test was applied, the third phase comprised changes in dimension in the items according to the theoretical basis investigated, and unified items that tourists considered repeated. Based on the results it was considered pertinent to complement alternatives and to disaggregate those with little acceptance among tourists to finally get to consider 44 items in the instrument.

Table 5 represents the fourth phase, in which the instrument was grouped into 6 dimensions: tourism, management, competitiveness and services complementary parts of the touristic product dimension, touristic price, touristic distribution, touristic promotion, touristic services and tourist profile. In this sense, several items were unified by their affinity and semantic writing, with the changes made, a 34-item instrument was obtained that was carried out in the two pilot tests and applied to 61 tourists, with intervals of one month, finally survey 610 tourists in the places with the highest score expressed according to the matrix of competitive advantage defined for the tourist destinations of Zone 3.

\subsection{Validation of the Measuring Instrument}

The validation process of the instrument was divided into two phases, qualitative and quantitative [49]. The first phase was obtained through valid processes such 
Table 2. Operationalization of variables as a function of satisfaction and their predictor variables.

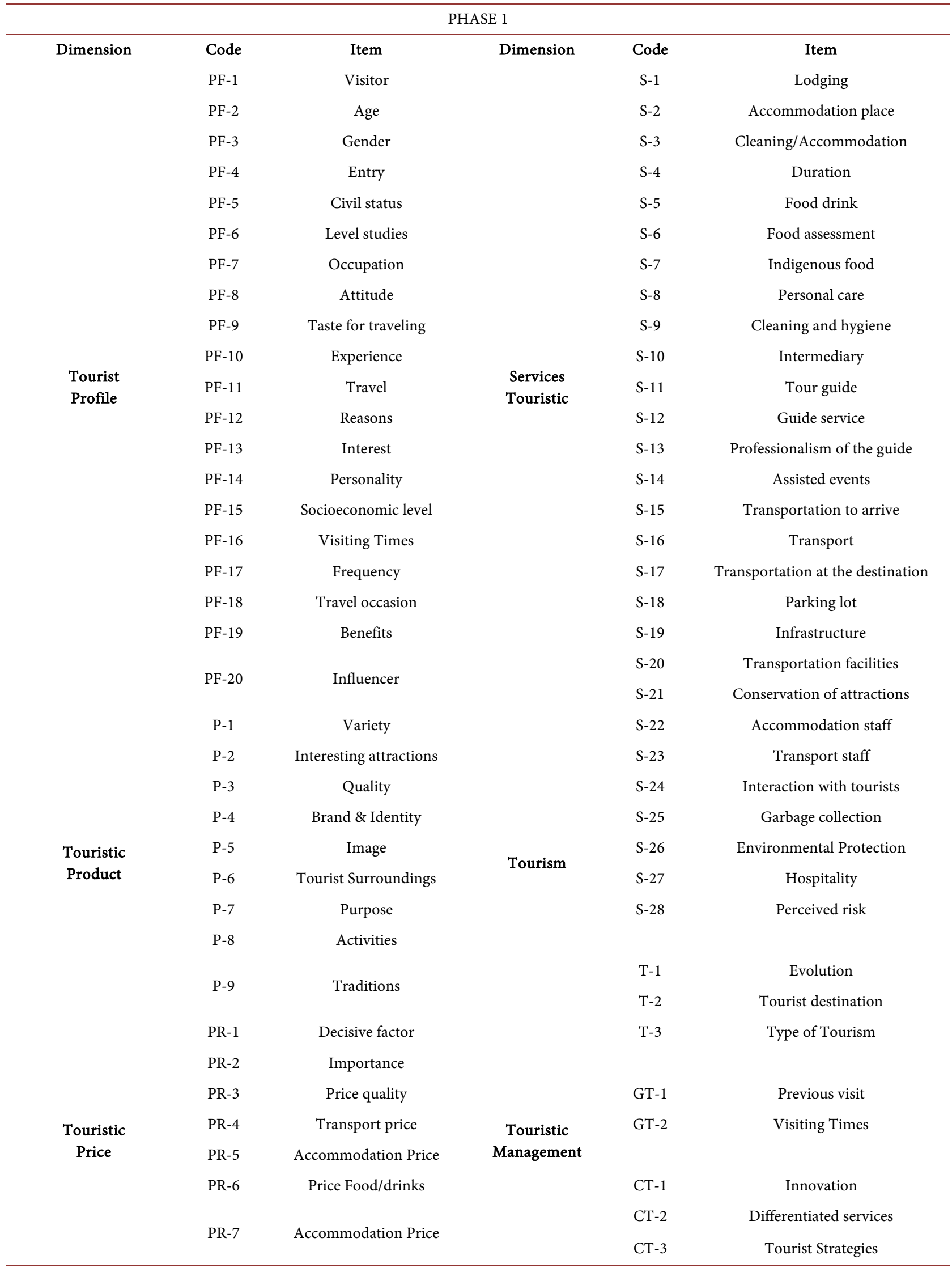




\section{Continued}

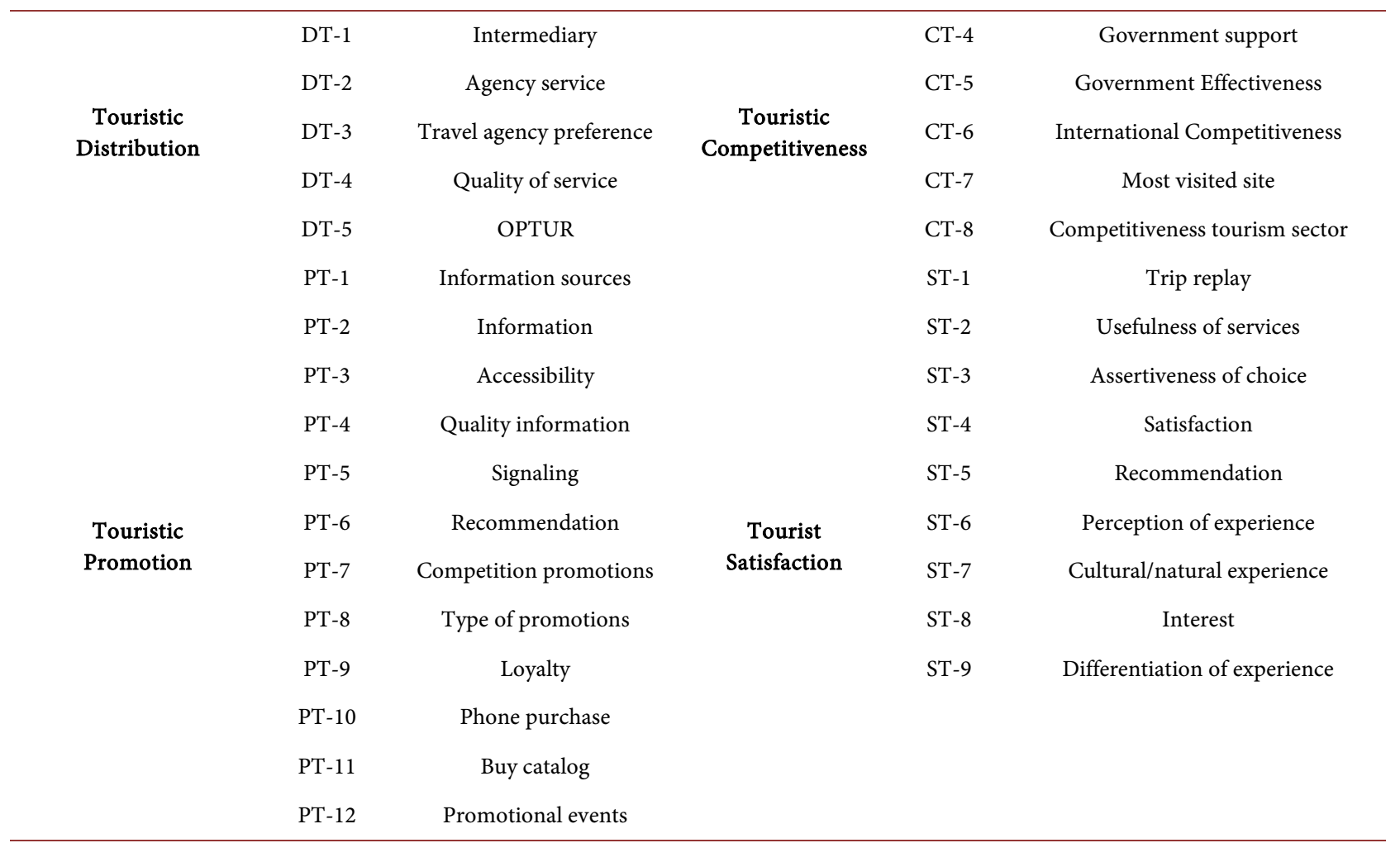

Note: The Code is described: coding of dimension questions. Item: study variable of each dimension. Observations: changes made to the item. Own elaboration.

Table 3. Modification of the instrument for the development of the pilot test.

\begin{tabular}{|c|c|c|c|c|c|c|c|}
\hline \multicolumn{8}{|c|}{ Phase 2-PILOT 1} \\
\hline Dimension & Code & Item & Observations & Dimension & Code & Item & Observations \\
\hline \multirow{15}{*}{$\begin{array}{l}\text { Tourist } \\
\text { Profile }\end{array}$} & $\mathrm{PF}-2$ & Age & No change & & S-12 & Guide service & \\
\hline & PF-3 & Gender & No change & & S-8 & Personal care & Unification \\
\hline & PF-4 & Entry & No change & & S-22 & Accommodation staff & \\
\hline & PF-5 & Civil status & No change & $\begin{array}{l}\text { Services } \\
\text { Touristic }\end{array}$ & S-11 & Tour guide & \\
\hline & PF-6 & Level studies & No change & & S-24 & Interaction with tourists & \\
\hline & PF-7 & Occupation & No change & & S-2 & Accommodation place & No change \\
\hline & PF-8 & Attitude & No change & & S-3 & Cleaning accommodation & \\
\hline & PF-10 & Experience & & & S-7 & Indigenous food & \\
\hline & PF-9 & Taste for traveling & Unification & & S-13 & Professionalism of the guide & \\
\hline & PF-16 & Visiting Times & & & S-16 & Transport & \\
\hline & PF-11 & Travel & No change & & S-18 & Parking lot & Unification \\
\hline & PF-13 & Interest & No change & & S-19 & Infrastructure & \\
\hline & PF-14 & Personality & No change & & S-20 & Transportation facilities & \\
\hline & PF-15 & Socioeconomic level & No change & & S-21 & Conservation of attractions & \\
\hline & PF-17 & Frequency of travel & No change & & S-23 & Transport staff & \\
\hline
\end{tabular}




\section{Continued}

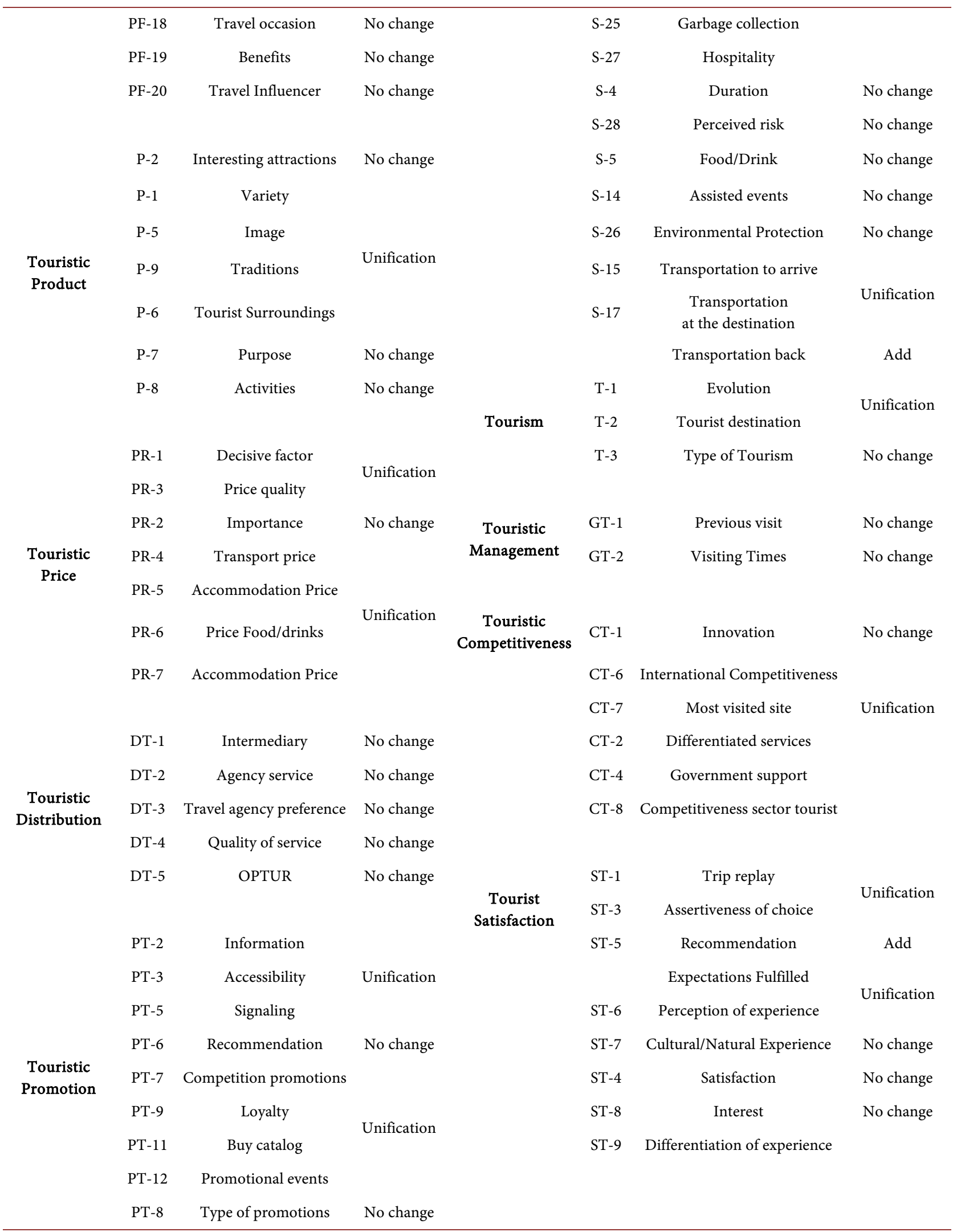

Note: The Code is described: coding of dimension questions. Item: study variable of each dimension. Observations: changes made to the item. Own elaboration. 
Table 4. Pilot test.

\begin{tabular}{|c|c|c|c|c|c|c|c|}
\hline \multicolumn{8}{|c|}{ Phase 3-PILOT 2} \\
\hline Dimension & Code & Item & Observations & Dimension & Code & Item & Observations \\
\hline \multirow{6}{*}{$\begin{array}{l}\text { Touristic } \\
\text { Product }\end{array}$} & $\mathrm{P}-1$ & Variety & & Services Touristic & S-26 & Environmental & No change \\
\hline & $\mathrm{P}-5$ & Image & Unification & & S-28 & $\begin{array}{c}\text { Protection } \\
\text { Perceived risk }\end{array}$ & No change \\
\hline & P-9 & Traditions & & & & & \\
\hline & P-6 & Tourist Surroundings & & & $\mathrm{T}-1$ & Evolution & Unification \\
\hline & P-7 & Purpose & No change & Tourism & $\mathrm{T}-2$ & Tourist destination & \\
\hline & P-8 & Activities & No change & & $\mathrm{T}-3$ & Type of tourism & No change \\
\hline \multirow{5}{*}{$\begin{array}{c}\text { Touristic } \\
\text { Price }\end{array}$} & PR-4 & Transport price & & $\begin{array}{c}\text { Touristic } \\
\text { Competitiveness }\end{array}$ & CT-1 & Innovation & No change \\
\hline & PR-5 & Accommodation Price & Unification & & CT-6 & $\begin{array}{c}\text { International } \\
\text { Competitiveness }\end{array}$ & Unification \\
\hline & PR-6 & Accommodation Price & & & & $\begin{array}{c}\text { Competitiveness } \\
\text { National }\end{array}$ & \\
\hline & & Price Fun & Add & & CT-2 & Differentiated services & \\
\hline & & & & & CT-4 & Government support & \\
\hline \multirow{9}{*}{$\begin{array}{c}\text { Touristic } \\
\text { distribution }\end{array}$} & PT-2 & Information & & & CT-8 & $\begin{array}{l}\text { Competitiveness } \\
\text { tourism sector }\end{array}$ & \\
\hline & PT-3 & Accessibility & $\begin{array}{l}\text { Change of } \\
\text { dimensions }\end{array}$ & & & & \\
\hline & PT-5 & Signaling & & & ST-6 & $\begin{array}{l}\text { Perception of } \\
\text { experience }\end{array}$ & Unification \\
\hline & & $\begin{array}{l}\text { Availability of } \\
\text { services/places }\end{array}$ & Add & & ST-7 & Natural experience & \\
\hline & DT-1 & Means used & $\begin{array}{l}\text { Modification } \\
\text { in writing }\end{array}$ & & & Cultural experience & \\
\hline & DT-2 & Service Purchased & No change & & ST-1 & Trip replay & \\
\hline & DT-3 & $\begin{array}{c}\text { Travel agency usage } \\
\text { preference }\end{array}$ & No change & $\begin{array}{c}\text { Tourist } \\
\text { Satisfaction }\end{array}$ & & Expectations Fulfilled & \\
\hline & DT-4 & Quality of service & No change & & ST-3 & Assertiveness of choice & \\
\hline & DT-5 & OPTUR & No change & & ST-5 & Recommendation & \\
\hline \multirow{9}{*}{$\begin{array}{l}\text { Touristic } \\
\text { Promotion }\end{array}$} & & & & & ST-9 & $\begin{array}{l}\text { Differentiation } \\
\text { of experience }\end{array}$ & \\
\hline & & Means of Information & Add & & ST-8 & Interest & \\
\hline & PT-7 & Competition promotions & & & S-24 & Interaction with tourists & \\
\hline & PT-9 & Loyalty & Unification & & & & \\
\hline & PT-12 & Promotional events & & $\begin{array}{c}\text { Touristic } \\
\text { Management }\end{array}$ & GT-2 & Visiting Times & No change \\
\hline & & Discounts & Add & & & & \\
\hline & & More services & Add & & PF-1 & Visitor & No change \\
\hline & PT-6 & Recommendation & No change & Tourist Profile & PF-2 & Age & No change \\
\hline & & & & & & Religion & Add \\
\hline
\end{tabular}




\begin{tabular}{|c|c|c|c|c|c|c|}
\hline & S-1 & Lodging & One question & PF-3 & Gender & No change \\
\hline & S-4 & Duration of stay & No change & PF-4 & Entry & No change \\
\hline & S-5 & Establishment used & $\begin{array}{l}\text { Complements } \\
\text { alternatives }\end{array}$ & PF-5 & Civil status & No change \\
\hline & & Kindness and respect & Add & PF-6 & Level studies & No change \\
\hline & S-12 & Guide service & No change & PF-7 & Occupation & No change \\
\hline & S-3 & Cleaning & Modification & PF-8 & Attitude & No change \\
\hline & S-7 & Indigenous food & & PF-10 & Experience & Unification \\
\hline & S-13 & $\begin{array}{l}\text { Professionalism } \\
\text { of the guide }\end{array}$ & & PF-9 & Taste for traveling & \\
\hline Services & S-16 & Transport & & PF-11 & Travel & No change \\
\hline Touristic & S-18 & Parking lot & & PF-13 & Personal interest & No change \\
\hline & S-19 & Infrastructure & Unification & PF-14 & Personality & No change \\
\hline & S-20 & Transportation facilities & & PF-15 & Socioeconomic level & No change \\
\hline & S-21 & $\begin{array}{l}\text { Conservation of } \\
\text { attractions }\end{array}$ & & PF-17 & Frequency of travel & No change \\
\hline & S-25 & Garbage collection & & PF-12 & Reasons & No change \\
\hline & S-27 & Hospitality & & PF-19 & Benefits & No change \\
\hline & S-14 & Assisted events & $\begin{array}{l}\text { Complements } \\
\text { alternatives }\end{array}$ & PF-20 & Influencer & No change \\
\hline & S-15-17 & Conveyance & $\begin{array}{l}\text { Complements } \\
\text { alternatives }\end{array}$ & & & \\
\hline
\end{tabular}

Note: The Code is described: coding of dimension questions. Item: study variable of each dimension. Observations: changes made to the item. Own elaboration.

Table 5. Instrument of measurement of the variable latent tourist satisfaction.

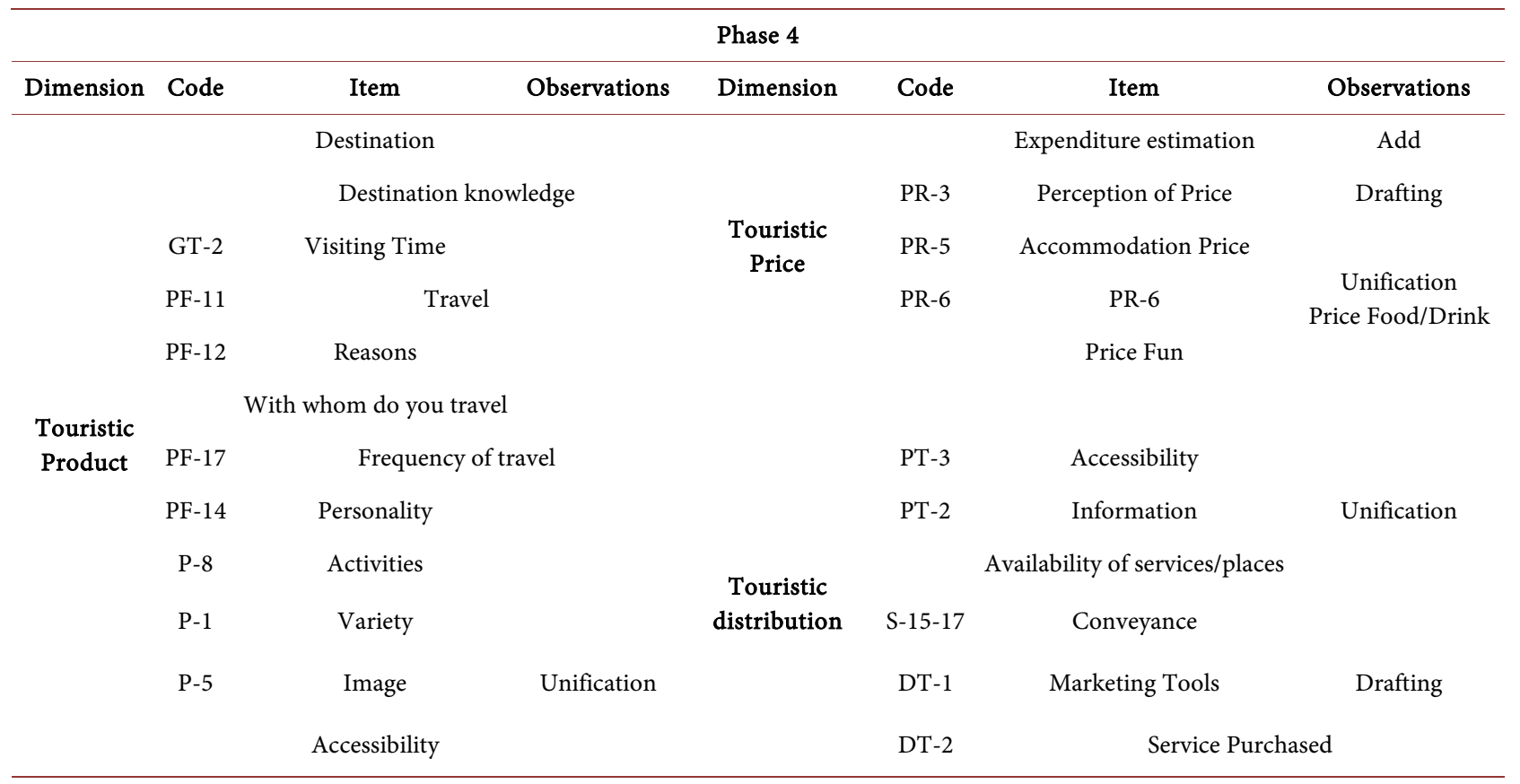




\section{Continued}

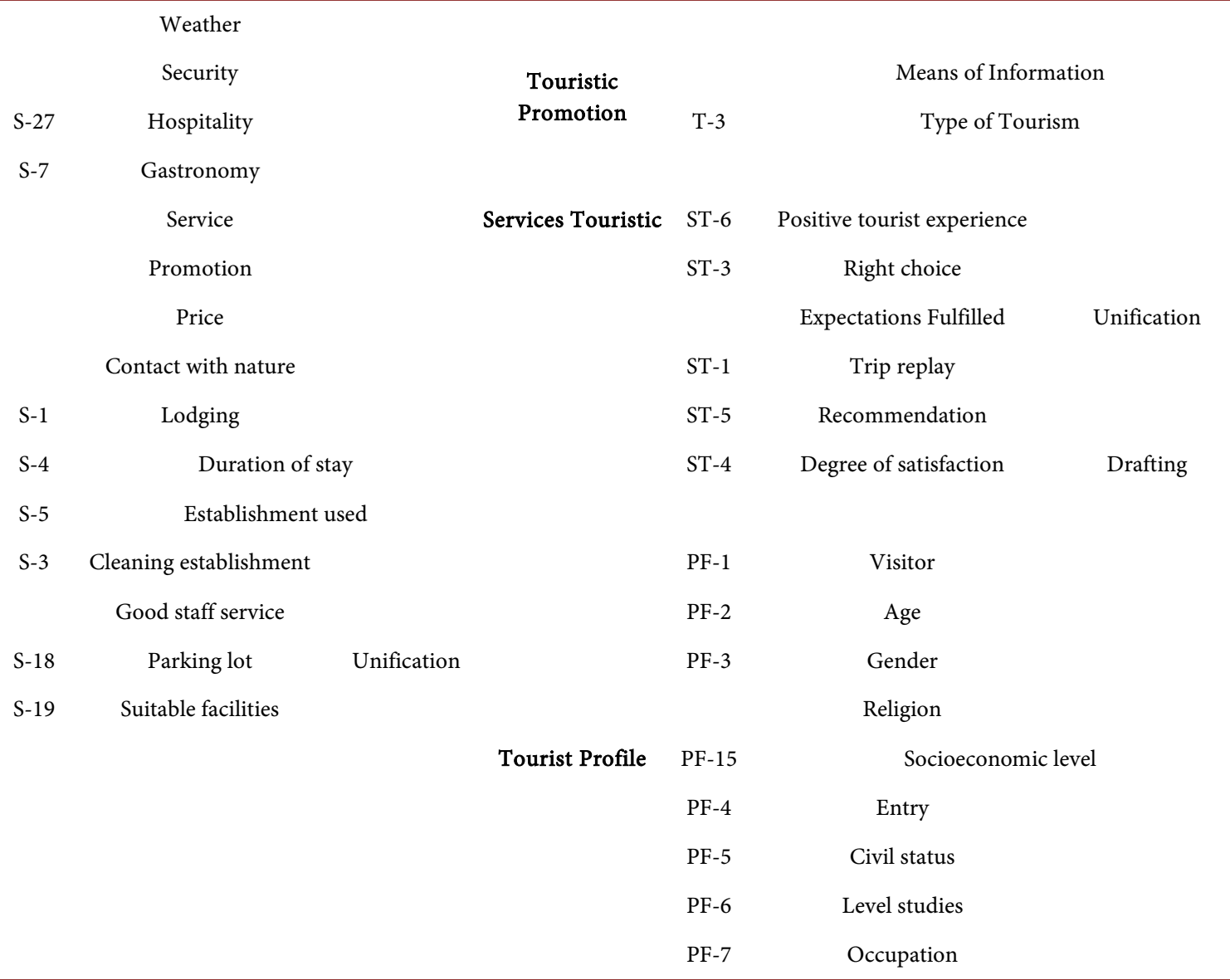

Note: The Code is described: coding of dimension questions. Item: study variable of each dimension. Observations: changes made to the item. Own elaboration.

as: meta-analysis, interviews with judges, experts, population and theoretical evidence. On the other hand, the second phase of the validity was developed with the determination of the internal validity of the instrument, the construct validity was established through the variance or discriminant capacity and the Pearson correlation with a coefficient of 0.784 [52], this meant construct validity of the instrument.

Reliability was focused on defining the reliability of the results reflected in the Cronbach Alpha which reached 0.71 and the reliability of the instrument was found to be acceptable. With the external validity the stability, concordance, criterion and performance of the instrument were evaluated. Stability was determined through the Pearson $\mathrm{R}$ coefficient, reaching a result of 1,000; the yield through the Diagnosis Curve or COR Curve reached a result of 0.635 determining the cut of the optimum point to measure sensitivity and specificity of the instrument.

\section{Results}

The analysis of results was done using the Least Squares technique in the Smart Plus 3.0 program [53]. The reliability of all the items used in the original survey 
applied to tourists was calculated and then discarded. Those items with reliability less than 0.70 , we developed the analysis of the coefficients that prove the validity of the proposed model with those items with loads greater than 0.70 and the individual reliability of the indicators was determined through the cross loads, complemented with the evaluation of the reliability of the scales Through the Cronbach Alpha.

The analysis of the Average Extracted Variance (AVE) allowed to determine the convergent validity of the proposed model and confirmed the discriminant validity, where each dimension differs from the other. The coefficient of determination $\left(R^{2}\right)$ and the Path $(\beta)$ coefficient allowed to evaluate the structural validity of the proposed model and an intense positive relation was obtained between the independent variables (product, price, distribution, promotion, services and tourist profile) and the dependent variable (tourist satisfaction).

The predictive relevance (Q2) of the proposed model was based on the Blindfolding technique in Smart Plus 3.0, which allowed us to affirm the hypotheses based on the relationship between the developed dimensions and tourist satisfaction; and as a complement the Bootstrapping technique determined the load of each of the indicators (items) of the sample, this allowed to elaborate the practical model, discarding the age due to its small sample load.

The analysis of the results under the Partial Least Squares (PLS) proposal was performed through the Smart PLS program [53]. Table 6 details the reliability of each of the dimensions calculated with the items of the survey that was applied to 610 tourists located in Zone 3, it is evident that the item "degree of satisfaction" has been excluded from the dimension "tourist services" immersed in the beginning of the investigation, because this indicator has been identified as fundamental for the measurement of the dependent variable "tourist satisfaction", and contributed more reliably in the survey developed with a 0.923 . On the contrary, the items with which the tourism product was evaluated contribute a 0.565 reliability, becoming the sensitive dimension of the instrument.

Table 7 shows the reliability of each dimension, calculated from variables whose reliability has been practically verified through surveys, detecting that Touristic Promotion is the strongest dimension with 1.0 of reliability. For this, it has been unwanted items with negative reliability or less than 0.70 .

Figure 1 shows the dimensions of the market that allowed to measure satisfaction of the tourist. Touristic promotion is highlighted as the dimension that contributes 1000 in reliability, and becomes the dimension with greater reliability and contributes to the practical model with the type indicator of tourism to promote in the place. On the contrary, the profile of the tourist contributes only the 0.786 of reliability to the model, and becomes the dimension with less contributes to the model: age, monthly income and occupation of the tourist.

\subsection{Individual Reliability of Indicators}

Table 8 presents the cross tables (second to eighth column) of the items (first column) that make up the model and analyzed the influence of product, price, 
Table 6. Dimension, variables, and reliability of the original study survey to measure tourist satisfaction in Zone 3.

\begin{tabular}{|c|c|c|c|}
\hline Dimension & & Variable & Reliability \\
\hline \multirow{6}{*}{$\begin{array}{c}\text { Touristic } \\
\text { Distribution }\end{array}$} & D3 & Ease of finding places & \multirow{6}{*}{0.759} \\
\hline & $\mathrm{D} 1$ & Availability of information & \\
\hline & $\mathrm{D} 2$ & Availability of services and places & \\
\hline & D6 & Transportation used & \\
\hline & $\mathrm{D} 4$ & Marketing Tools & \\
\hline & D5 & Services acquired in marketing tools & \\
\hline \multirow{8}{*}{ Tourist Profile } & PE1 & Visitor & \multirow{11}{*}{0.691} \\
\hline & PE2 & Age & \\
\hline & PE3 & Gender & \\
\hline & PE4 & Religion & \\
\hline & PE5 & Socioeconomic level & \\
\hline & PE6 & Monthly income & \\
\hline & PE7 & Civil status & \\
\hline & PE8 & Level of studies & \\
\hline \multirow{6}{*}{ Touristic Price } & PE9 & Occupation & \\
\hline & PR1 & Estimated expenditure & \\
\hline & PR2 & Perception of price & \\
\hline & PR3 & Price of food and drinks & \multirow[t]{3}{*}{0.732} \\
\hline & PR4 & Activities & \\
\hline & PR5 & Accommodation Price & \\
\hline \multirow{16}{*}{ Touristic Product } & P9 & Destination & \multirow{16}{*}{0.565} \\
\hline & P6 & Prior knowledge & \\
\hline & P27 & Times of visit & \\
\hline & P3 & Aspects for planning & \\
\hline & P19 & The reason of the visit & \\
\hline & P8 & With whom do you travel & \\
\hline & $\mathrm{P} 12$ & Frequency of travel & \\
\hline & $\mathrm{P} 20$ & Personality & \\
\hline & $\mathrm{P} 2$ & Activities performed & \\
\hline & P26 & Variety & \\
\hline & P15 & Image & \\
\hline & $\mathrm{P} 1$ & Accessibility & \\
\hline & P5 & Weather & \\
\hline & $\mathrm{P} 22$ & Security & \\
\hline & P14 & Hospitality & \\
\hline & $\mathrm{P} 13$ & Gastronomy & \\
\hline
\end{tabular}




\section{Continued}

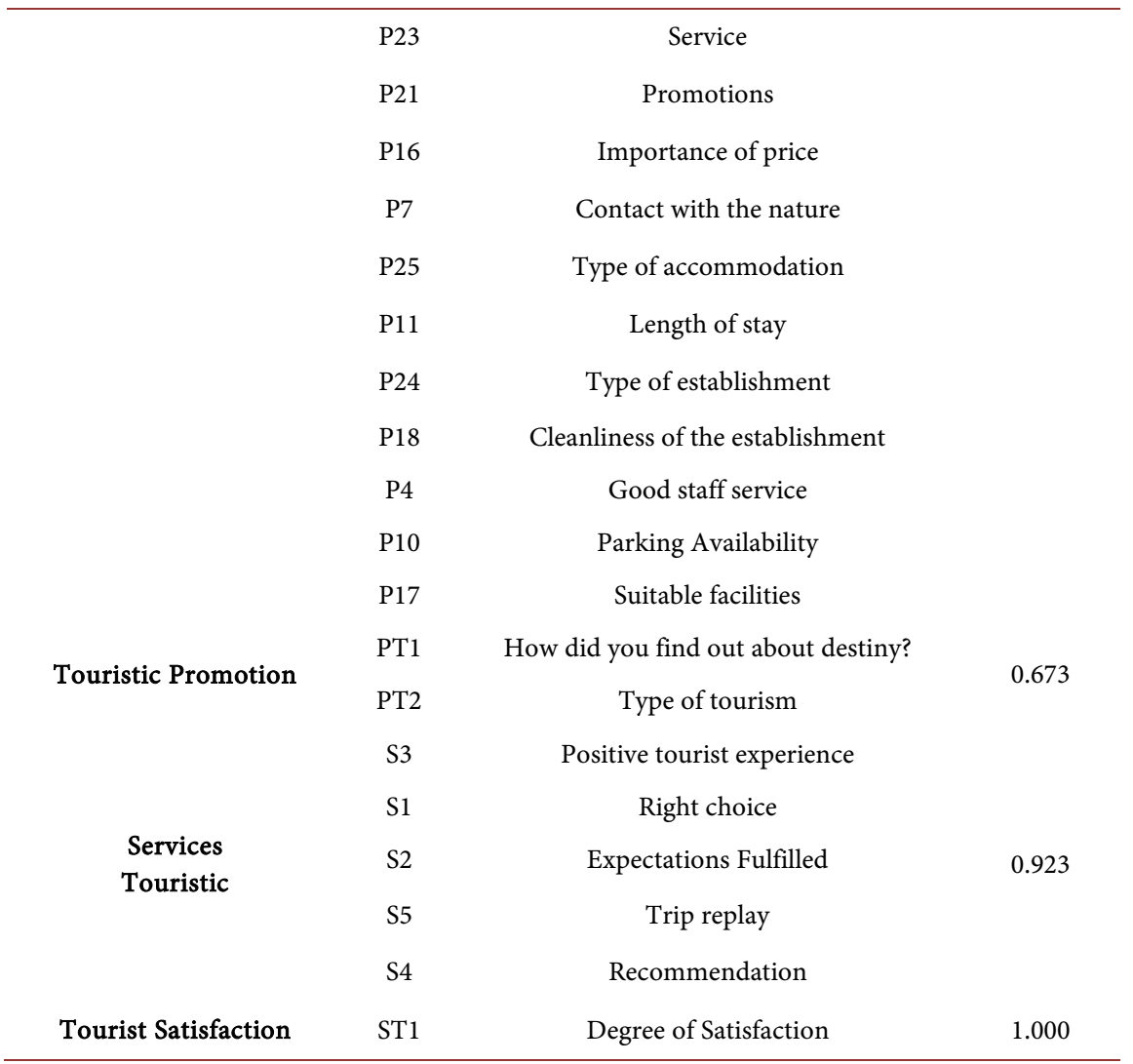

Note: Reliability of the entire original survey by dimensions. Adapted from "Smart Plus 3.0" by C Ringle, S. Wende, \& J. Becker, 2015.

Table 7. Shows the reliability of the dimensions, analyzed from variables according to the reliability practically proven through the surveys.

\begin{tabular}{ccc}
\hline Dimension & Variable & Reliability \\
\hline $\begin{array}{c}\text { Touristic } \\
\text { Distribution }\end{array}$ & $\begin{array}{c}\text { Ease of finding places } \\
\text { Availability of information } \\
\text { Availability of services and places }\end{array}$ & 0.882 \\
Tourist Profile & Age & 0.786 \\
& Monthly income \\
Occupation & \\
Touristic Price & Price of food and drinks & 0.899 \\
& Activities & \\
Touristic Product & Cleanliness of the establishment \\
& Good staff service \\
& Parking Availability \\
Suitable facilities & 0.897 \\
Touristic Promotion & Type of tourism & 1.000 \\
& Positive tourist experience & \\
Services & Right choice & \\
Touristic & Trip replay & 0.926 \\
& Recommendation &
\end{tabular}

Note: Own elaboration based on surveys. 
Table 8. Cross loadings between the indicators of the model to analyze tourist satisfaction.

\begin{tabular}{|c|c|c|c|c|c|c|c|}
\hline Item & $\begin{array}{c}\text { Touristic } \\
\text { Distribution }\end{array}$ & $\begin{array}{l}\text { Tourist } \\
\text { Profile }\end{array}$ & $\begin{array}{l}\text { Touristic } \\
\text { Price }\end{array}$ & $\begin{array}{l}\text { Touristic } \\
\text { Product }\end{array}$ & $\begin{array}{l}\text { Touristic } \\
\text { Promotion S }\end{array}$ & $\begin{array}{c}\text { Tourist } \\
\text { Satisfaction }\end{array}$ & $\begin{array}{l}\text { Services } \\
\text { Touristic }\end{array}$ \\
\hline $\begin{array}{l}\text { Easy to } \\
\text { find places }\end{array}$ & 0.860 & -0.056 & 0.195 & 0.325 & 0.092 & 0.104 & 0.204 \\
\hline $\begin{array}{c}\text { Availability of } \\
\text { services and places }\end{array}$ & 0.889 & -0.122 & 0.217 & 0.357 & 0.025 & 0.027 & 0.170 \\
\hline $\begin{array}{l}\text { Availability of } \\
\text { information }\end{array}$ & 0.824 & -0.096 & 0.111 & 0.299 & -0.026 & 0.057 & 0.144 \\
\hline Age & -0.097 & 0.618 & -0.057 & -0.047 & 0.008 & -0.003 & -0.046 \\
\hline Monthly income & -0.065 & 0.833 & -0.223 & -0.153 & 0.050 & 0.169 & -0.069 \\
\hline Occupation & -0.102 & 0.775 & -0.212 & -0.083 & 0.003 & 0.135 & 0.012 \\
\hline $\begin{array}{c}\text { Price of } \\
\text { food/drinks }\end{array}$ & 0.285 & -0.238 & 0.925 & 0.334 & 0.171 & -0.209 & 0.215 \\
\hline Fun price & 0.065 & -0.220 & 0.876 & 0.073 & 0.264 & -0.284 & 0.209 \\
\hline $\begin{array}{l}\text { Availability } \\
\text { parking lot }\end{array}$ & 0.341 & -0.024 & 0.127 & 0.792 & 0.053 & 0.087 & 0.240 \\
\hline Good service & 0.312 & -0.179 & 0.233 & 0.879 & 0.020 & 0.063 & 0.266 \\
\hline $\begin{array}{c}\text { Suitable } \\
\text { installations }\end{array}$ & 0.364 & -0.114 & 0.210 & 0.853 & 0.082 & 0.050 & 0.249 \\
\hline $\begin{array}{c}\text { Cleaning } \\
\text { establishment }\end{array}$ & 0.265 & -0.161 & 0.240 & 0.827 & 0.029 & 0.046 & 0.260 \\
\hline $\begin{array}{l}\text { Promote } \\
\text { tourism }\end{array}$ & 0.040 & 0.033 & 0.235 & 0.055 & 1.000 & -0.047 & 0.154 \\
\hline $\begin{array}{c}\text { Degree of } \\
\text { satisfaction }\end{array}$ & 0.073 & 0.173 & -0.268 & 0.073 & -0.047 & 1.000 & 0.099 \\
\hline Right choice & 0.201 & -0.062 & 0.192 & 0.291 & 0.032 & 0.079 & 0.834 \\
\hline $\begin{array}{l}\text { Expectations } \\
\text { fulfilled }\end{array}$ & 0.070 & 0.006 & 0.163 & 0.155 & 0.134 & 0.068 & 0.813 \\
\hline $\begin{array}{c}\text { Experience } \\
\text { positive tourism }\end{array}$ & 0.207 & -0.034 & 0.257 & 0.230 & 0.199 & 0.062 & 0.825 \\
\hline Recommendation & 0.205 & -0.054 & 0.209 & 0.337 & 0.137 & 0.125 & 0.869 \\
\hline Repeat trip & 0.116 & -0.014 & 0.132 & 0.202 & 0.142 & 0.067 & 0.858 \\
\hline
\end{tabular}

Note: Own elaboration based on surveys.

distribution, promotion, services and tourist profile on tourist satisfaction, correlations greater than 0.707 are shown in each construct of the dimensions, except for the age with a correlation of 0.618 . The individual reliability of each indicator is checked, however, it is observed that the items with higher contribution are "food and beverage price" with 0.925 to the tourist price dimension; "type of tourism to promote" with 1000 in the dimension of tourism promotion. 


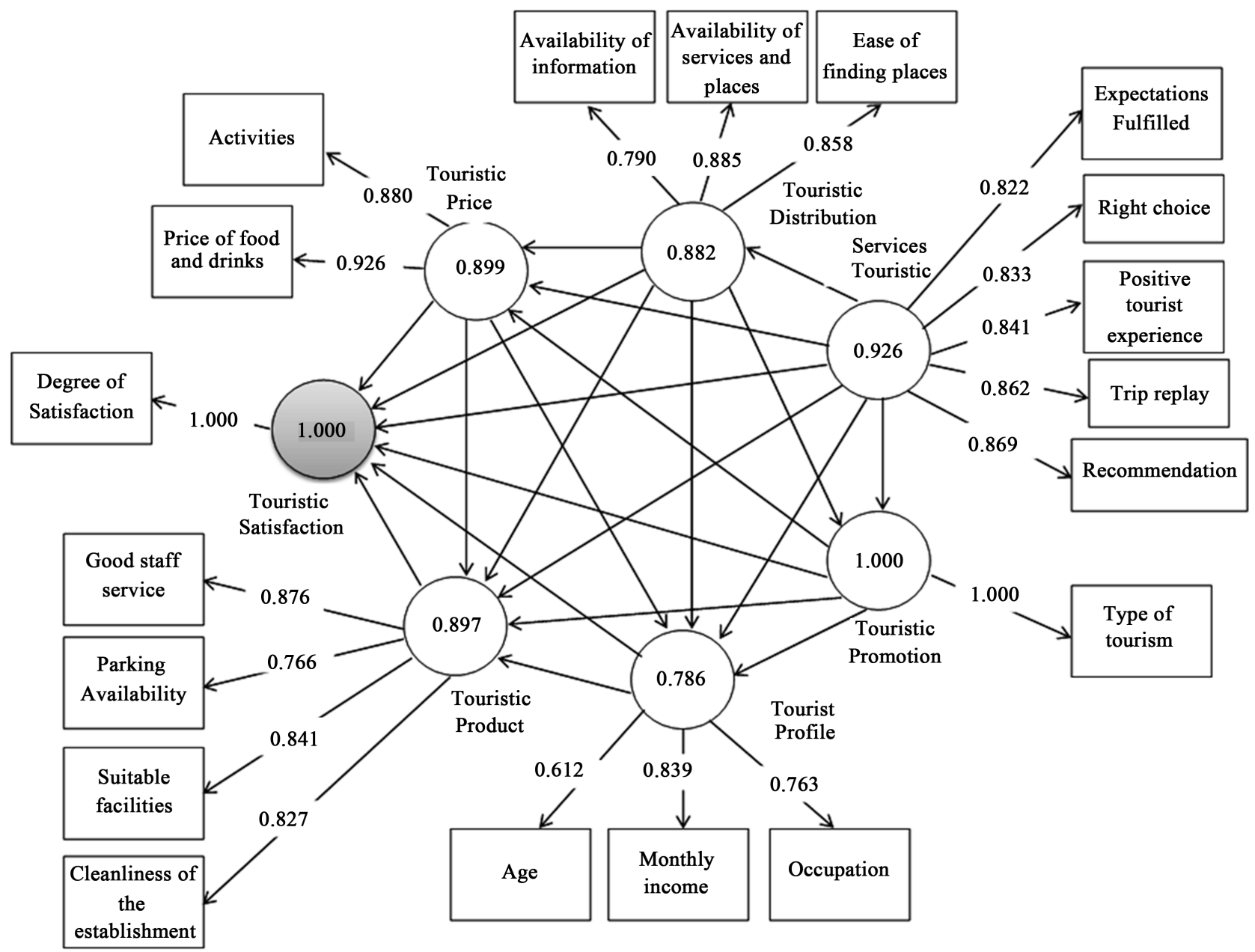

Figure 1. Dimension, variables, and reliability of the practical model to measure tourist satisfaction in Zone 3.

\subsection{Internal Consistency or Reliability of the Scales}

The analysis of calculated values for the composite reliability of the constructs part of the model and determine the influence of the product, price, distribution, promotion, services and the tourist profile in tourist satisfaction (column one of Table 9) To appreciate that all values are higher than 0.70 (column two of Table 9) and it is evident that the indicators measure what each construct is supposed to measure. Therefore, we conclude that the model has internal consistency.

Table 10 shows the reliability of the scales to analyze the influence of product, price, distribution, promotion, services and the profile on tourist satisfaction has a Cronbach alpha higher than 0.70; however the profile reveals 0.652 this means that it does not meet the parameter of 0.70 ; it is concluded that there is reliability of the scales in the survey.

\subsection{Convergent Validity}

Table 11 shows that the constructs of the dimensions (first column) of the model developed to determine their influence on Tourist Satisfaction in Zone three have an average variance extracted (second column) higher than 0.50 . It is verified that the model has convergent validity. The 0.703 of the AVE of the tourism 
Table 9. Reliability of the model to analyze tourist satisfaction.

\begin{tabular}{cc}
\hline Variable & Composite Reliability \\
\hline Touristic product & 0.904 \\
Touristic Price & 0.896 \\
Touristic Distribution & 0.893 \\
Touristic Promotion & 1.000 \\
Services Touristic & 0.923 \\
Tourist Profile & 0.789 \\
\hline
\end{tabular}

Note: Own elaboration based on surveys.

Table 10. Cronbach's alpha of the model to analyze tourist satisfaction.

\begin{tabular}{cc}
\hline Dimensión & Alfa de Cron Bach \\
\hline Touristic Distribution & 0.834 \\
Tourist Profile & 0.652 \\
Touristic Price & 0.800 \\
Touristic Product & 0.862 \\
Touristic Promotion & 1.000 \\
Services Touristic & 0.918 \\
\hline
\end{tabular}

Note: Own elaboration based on surveys.

Table 11. Variance of the variables of tourist satisfaction.

\begin{tabular}{cc}
\hline Variable & Varianza promedio extraída (AVE) \\
\hline Touristic Product & 0.703 \\
Touristic Price & 0.811 \\
Touristic Distribution & 0.736 \\
Touristic Promotion & 0.551 \\
Services Touristic & 0.706 \\
Tourist Profile & 0.559 \\
\hline
\end{tabular}

Note: Own elaboration based on surveys.

product construct was calculated by indicators such as good staff service, availability of parking, adequate facilities and cleanliness of establishments; the 0.811 of the variance of the tourist price was calculated according to the price of food and drinks, and price of diversion; the 0.736 of the variance of the tourist distribution was obtained from variables like the availability of information, availability of services places and facility to find places; the 0.551 variance of the promotion was calculated from variables, type of tourism to promote and how he learned of the destination; the 0.706 of the variance of tourist services was calculated from indicators such as expectations fulfilled, successful choice, positive tourism experience, repetition of the trip and recommendation; the 0.559 of the variance was reached from the age, monthly income and occupation of the tourist. 


\subsection{Discriminant Validity}

Table 12 shows the average variances extracted based on the Fornell-Larcker criterion of the constructs of the practical model developed (from the third to the ninth column), and the values are explicitly shown to the square root of the variance that are superior to the correlations with other dimensions that are part of the model; and it is concluded that the dimensions of the practical model (first column Table 12) are different from each other and it has discriminant validity.

\subsection{Evaluation of the Structural Model}

Table 13 shows the coefficient of determination R squared (second column) that was analyzed of the independent variables of the model (first column), it is observed that the product, price, distribution, promotion, tourist profile and touristic services independent participate with a percentage of the total variance higher than 0.10 this reveals that the dependent variable (tourist satisfaction) is a predictor of product, price, distribution, promotion, tourist profile and touristic services.

Table 12. Cross-variances between the constructs of the model to analyze tourist satisfaction.

\begin{tabular}{|c|c|c|c|c|c|c|c|c|}
\hline Variable & AVE & $\begin{array}{c}\text { Touristic } \\
\text { Distribution }\end{array}$ & $\begin{array}{l}\text { Tourist } \\
\text { Profile }\end{array}$ & $\begin{array}{l}\text { Touristic } \\
\text { Price }\end{array}$ & $\begin{array}{c}\text { Touristic } \\
\text { Product }\end{array}$ & $\begin{array}{l}\text { Touristic } \\
\text { Promotion }\end{array}$ & $\begin{array}{c}\text { Tourist } \\
\text { Satisfaction }\end{array}$ & $\begin{array}{l}\text { Services } \\
\text { Touristic }\end{array}$ \\
\hline $\begin{array}{c}\text { Touristic } \\
\text { Distribution }\end{array}$ & 0.736 & 0.858 & & & & & & \\
\hline $\begin{array}{l}\text { Tourist } \\
\text { Profile }\end{array}$ & 0.559 & 0.106 & 0.747 & & & & & \\
\hline $\begin{array}{c}\text { Touristic } \\
\text { Price }\end{array}$ & 0.811 & 0.208 & 0.255 & 0.901 & & & & \\
\hline $\begin{array}{l}\text { Touristic } \\
\text { Product }\end{array}$ & 0.703 & 0.383 & 0.144 & 0.242 & 0.839 & & & \\
\hline $\begin{array}{l}\text { Touristic } \\
\text { Promotion }\end{array}$ & 0.551 & 0.019 & 0.031 & 0.244 & 0.064 & 0.758 & & \\
\hline $\begin{array}{c}\text { Tourist } \\
\text { Satisfaction }\end{array}$ & 1.000 & 0.073 & 0.173 & 0.268 & 0.073 & 0.047 & 1.000 & \\
\hline $\begin{array}{l}\text { Services } \\
\text { Touristic }\end{array}$ & 0.706 & 0.203 & 0.043 & 0.235 & 0.303 & 0.154 & 0.099 & 0.840 \\
\hline
\end{tabular}

Note: Own elaboration based on surveys.

Table 13. Coefficient of determination of the model to analyze tourist satisfaction.

\begin{tabular}{ccc}
\hline Variable & R cuadrado & R cuadrado ajustada \\
\hline Touristic Distribution & 0.141 & 0.140 \\
Tourist Profile & 0.177 & 0.171 \\
Touristic Price & 0.122 & 0.117 \\
Touristic Product & 0.220 & 0.213 \\
Touristic Promotion & 0.124 & 0.121 \\
Services Touristic & 0.130 & 0.121 \\
\hline
\end{tabular}

Note: Own elaboration based on surveys. 
In the analysis of the path $(\beta)$ values of the model, it can be seen in Table 14 that the dependent variable (Tourist satisfaction) presented a Path $(\beta)$ value of 0.203 on the independent variable (Touristic Distribution); 0.440 on the variable independent tourist profile; 0.537 on the independent tourist price variable; 0.548 on the independent variable tourist product; 0.161 on the independent tourism promotion variable; and 0.306 on the independent variable tourist services. The values reached are higher than 0.20 , except for 0.161 that complies with the parameter, which concludes that the model has structural validity and there is a positive relationship between the dependent variable and the independent variables.

Table 15 summarizes the quality criteria analyzed using the Least Squares (PLS) technique. The first column shows the reliability calculated through the Cronbach alpha with values greater than 0.707 in all dimensions [54]. This guarantees that the shared variance between the construct and its indicators is greater than the variance of error, including the dimension that evaluates the profile of the tourist who registers 0.652 that with the corresponding approximation satisfies the parameter, this proves the reliability of the scales used in the constructs, therefore there is internal validity of the developed model.

The coefficient of determination $\left(\mathrm{R}^{2}\right)$ of the dependent variables found in the second column exceeds 0.10 For [55] and [56] propose that the explained variance of the dependent variables should be greater or equal to 0.10 and if it were lower it would provide very little information. Thus confirming that Tourist Satisfaction (dependent variable) is determinant of the product, price, distribution, promotion, tourist profile and touristic services. According to [57] cited by [55] the average extracted variance (AVE) (fourth column) of each variable is greater than 0.50 , this confirms that the model developed has convergent validity. Higher

Table 14. Model coefficients for analyzing tourist satisfaction.

\begin{tabular}{ccccccc}
\hline Variable & $\begin{array}{c}\text { Touristic } \\
\text { Distribution }\end{array}$ & $\begin{array}{c}\text { Tourist } \\
\text { Profile }\end{array}$ & $\begin{array}{c}\text { Touristic } \\
\text { Price }\end{array}$ & $\begin{array}{c}\text { Touristic } \\
\text { Product }\end{array}$ & $\begin{array}{c}\text { Touristic } \\
\text { Promotion }\end{array}$ & $\begin{array}{c}\text { Services } \\
\text { Touristic }\end{array}$ \\
\hline $\begin{array}{c}\text { Tourist } \\
\text { Satisfaction }\end{array}$ & 0.203 & 0.440 & 0.537 & 0.548 & 0.161 & 0.306
\end{tabular}

Note: Own elaboration based on surveys.

Table 15. Quality criteria.

\begin{tabular}{cccccc}
\hline Dimension & $\begin{array}{c}\text { Cronbach } \\
\text { alpha }\end{array}$ & $\mathbf{R}^{2}$ & $\begin{array}{c}\text { Average variance } \\
\text { extracted (AVE) }\end{array}$ & $\begin{array}{c}\text { Path } \\
\text { coefficients }(\beta)\end{array}$ & $\begin{array}{c}\mathbf{Q}^{2} \\
(=1-S S E / S S O)\end{array}$ \\
\hline Touristic Distribution & 0.834 & 0.141 & 0.736 & 0.203 & 0.021 \\
Tourist Profile & 0.652 & 0.177 & 0.559 & 0.440 & 0.028 \\
Touristic Price & 0.800 & 0.122 & 0.811 & 0.537 & 0.093 \\
Touristic Product & 0.862 & 0.220 & 0.703 & 0.548 & 0.116 \\
Touristic Promotion & 1.000 & 0.124 & 0.551 & 0.161 & 0.022 \\
Services Touristic & 0.918 & 0.130 & 0.706 & 0.306 & 0.098 \\
Tourist Satisfaction & 1.000 & & & & \\
\hline
\end{tabular}

Note: $\mathrm{R}^{2}=$ Correlation coefficient, $\mathrm{Q}^{2}=$ Predictive relevance. Own elaboration based on surveys. 
than 0.50 so that it can be guaranteed that more than $50 \%$ of the variance of the construct is due to the indicators and not to the error.

Within the coefficient Path ( $\beta$ ) (fifth column) is reflected values higher than 0.20 , except for 0,161 that complies with the parameter [58] which concludes that the model has structural validity and there is a positive relation between the independent variable (Tourist Satisfaction) and the independent variables (product, price, distribution, promotion, tourist profile and touristic services).

Finally, we have evaluated the predictive relevance of the construct through Blindfolding in Smart Plus 3.0, and we obtain that Q2 is greater than zero, thus reflecting the predictive validity of the model developed [59].

Table 16 shows the results of Bootstraping and the loads of the indicators of the 610 surveys applied to the tourists and visitors of Zone three, with a level of significance $(\mathrm{P})$ of 0.05 .

Table 16. Bootstrapping of the loads of the model indicators to analyze tourist satisfaction.

\begin{tabular}{|c|c|c|c|c|c|}
\hline Item-Constructo & $\begin{array}{c}\text { Loads } \\
\text { Original } \\
\text { sample (O) }\end{array}$ & $\begin{array}{c}\text { Sample } \\
\text { Mean } \\
\text { (M) }\end{array}$ & $\begin{array}{l}\text { Standard } \\
\text { deviation }\end{array}$ & $\mathrm{T}$ & $\mathbf{P}$ \\
\hline \multicolumn{6}{|l|}{ Hypothesis 1} \\
\hline Good staff service $<-$ touristic product & 0.811 & 0.81 & 0.037 & 21.863 & 0 \\
\hline Suitable facilities <- touristic product & 0.825 & 0.823 & 0.053 & 15.55 & 0 \\
\hline Cleaning of premises $<-$ touristic product & 0.738 & 0.74 & 0.051 & 14.51 & 0 \\
\hline Parking available $<-$ touristic product & 0.735 & 0.726 & 0.058 & 12.625 & 0 \\
\hline \multicolumn{6}{|l|}{ Hypothesis 2} \\
\hline Fun price $<-$ touristic Price & 0.703 & 0.707 & 0.042 & 16.821 & 0 \\
\hline Price of food and drinks <- touristic price & 0.89 & 0.888 & 0.041 & 21.832 & 0 \\
\hline \multicolumn{6}{|l|}{ Hypothesis 3} \\
\hline Easy to find places <- touristic distribution & 0.818 & 0.813 & 0.059 & 13.778 & 0 \\
\hline $\begin{array}{c}\text { Availability of services and } \\
\text { places }<- \text { touristic distribution }\end{array}$ & 0.851 & 0.853 & 0.048 & 17.65 & 0 \\
\hline Availability of information $<-$ touristic distribution & 0.66 & 0.658 & 0.071 & 9.261 & 0 \\
\hline \multicolumn{6}{|l|}{ Hypothesis 4} \\
\hline Tourism to promote $<-$ touristic promotion & 1 & 1 & 0 & & \\
\hline \multicolumn{6}{|l|}{ Hypothesis 5} \\
\hline Age $<-$ profile of the tourist & 0.172 & 0.195 & 0.115 & 1.494 & 0.136 \\
\hline Monthly income <- profile of the tourist & 0.750 & 0.728 & 0.09 & 8.377 & 0 \\
\hline Occupation <- profile of the tourist & 0.624 & 0.618 & 0.088 & 7.117 & 0 \\
\hline \multicolumn{6}{|l|}{ Hypothesis 6} \\
\hline Successful choice $<-$ touristic services & 0.812 & 0.804 & 0.065 & 12.41 & 0 \\
\hline Expectations fulfilled $<-$ touristic services & 0.543 & 0.553 & 0.075 & 7.226 & 0 \\
\hline Positive tourism experience $<-$ touristic services & 0.901 & 0.897 & 0.068 & 13.338 & 0 \\
\hline Recommendation <- touristic services & 0.98 & 0.967 & 0.054 & 18.134 & 0 \\
\hline Repetition of the journey $<-$ touristic services & 0.621 & 0.625 & 0.065 & 9.622 & 0 \\
\hline
\end{tabular}

Note: $\mathrm{T}=$ Student $\mathrm{T} ; \mathrm{P}=$ Estimation error level. Own elaboration based on surveys. 


\subsection{Hypothesis Testing}

The Path coefficient of the independent variables that was evaluated in the product, price, distribution; promotion; tourist profile and services (fifth column, Table 16) exceeds the parameter of 0.20 this shows a consistent relationship with the dependent variable tourist satisfaction; in the sixth column the estimation error level (P) is less than 0.05 maximum error allowed and the $\mathrm{Q}^{2} \mathrm{Is}$ greater than zero. Thus, hypotheses $1,2,3,4,5$ are predictors of tourist satisfaction.

The tourism market and satisfaction validated through the least squares technique is presented in Figure 2.

\section{Conclusions}

The origin of the visits of a destination is oriented to national and foreign tourists [45], and who consider the economic resources and the trip planning for the making-decisions. In addition, they are motivated to make the holidays in the company of family, friends; and their favorite establishments

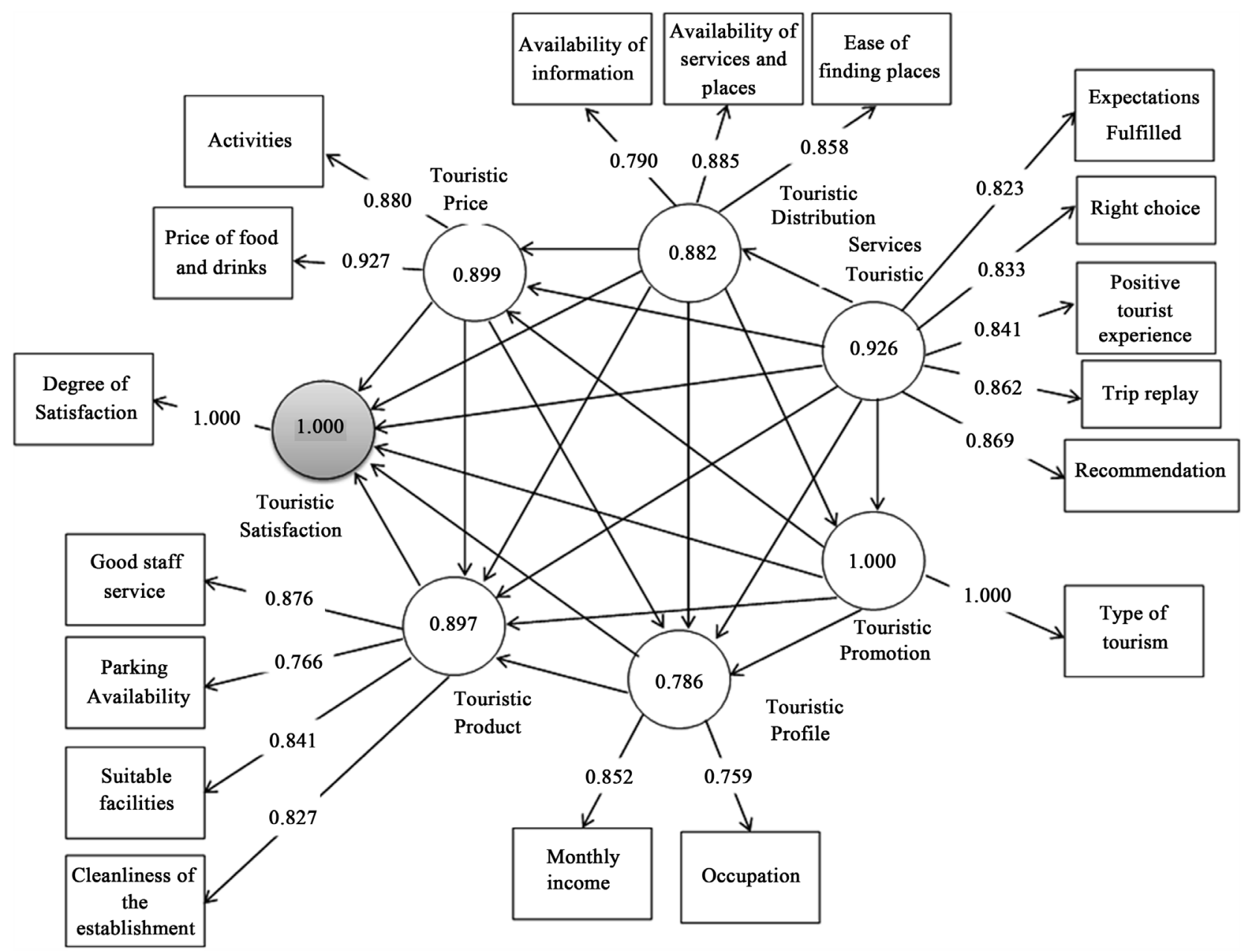

Figure 2. Practical model to determine the influence of the product, price, distribution, promotion, services and tourist profile on tourist satisfaction in Zone 3. 
for accommodation are hotels making use of restaurants and cafes for the consumption of food and beverages [60] [61].

The variables that evaluate the influence of the touristic product on tourist satisfaction [62], tourists value the good service of the staff, adequate facilities, cleanliness of the establishments and availability of parking, the coefficient Path shows an intense and acceptable relation of 0.548 obtaining predictive relevance of the construct [63].

The touristic price is identified as a main factor that influences the decision to purchase a service [64], is related to the degree of satisfaction of the tourists and a moderate range of payment of drinks is obtained, feeding and fun activities, whose predictive relevance is reflected in the Path coefficient and is acceptable with 0.537 [65] [66].

In the touristic distribution [67], the availability of information, the ease of finding places, services and places in the destination [68], this allows tourists to take important information, time, form and place required, to achieve a positive satisfaction in the destination visited, thus determining its predictive relevance through the Path coefficient of 0.203 considered acceptable [69].

The visiting season of domestic and foreign tourists should be aligned with the characteristics of the offer according to the identified tourism segments [31], the lack of knowledge and the lack of promotion of the destination diminish the flow of tourists, mostly tourists they visit the destination on their own initiative. Foreign tourists value the distance between the country of origin and the receiving destination of the tourist. They also appreciate the promotion of cultural and gastronomic tourism as propitious scenarios to know the origin of the cities [70]. Therefore, the variable that evaluates the influence of tourism promotion on tourist satisfaction corresponds to the type of tourism to be promoted in the destination, which is reflected in its predictive relevance on the dependent variable in the Path coefficient of 0.161 [71].

The variables of influence of touristic services on tourist satisfaction [72], respond to the correct choice of the place, fulfillment of their expectations, positive tourism experience, recommendation and repetition of the trip [73], and determined predictive relevance of the variables as evidenced in the Path coefficient of 0.306 [74].

The main characteristics identified in the profile of the tourist [75], highlights the perceptions and attitudes of these [76], who are in a 90.5\% between quite and very satisfied valued with an ordinal scale of 1 to 5 .

The findings related to the limitations of the study were that no theoretical evidence or previous studies were found in Zone Three of Ecuador that includes the provinces of Chimborazo, Cotopaxi, Pastaza, and Tungurahua. This did not allow to assure a study population with certain essential characteristics in the international tourists, a situation that complicates for the application of a probabilistic technique with known sample frame. In addition, the eligibility, exclusion, and constraints at the time of choosing the units of analysis resulted in a cross-sectional design, with a single measurement of the object of study. Another 
limitation was the context and the locations in which the data were collected, since there was no prior agreement or payment to the participants who completed the surveys because of the limited research budget.

As future lines of research to fill the gaps of this study can be derived the image of the tourist destination from the point of view of foreign and national tourist. In addition, it is fundamental to study the personal motivations that encourage tourists to visit the destination to value the image according to their perception. Finally, trigger in tourist cluster defining routes and connections considering the tastes and preferences according to the types of tourism.

\section{References}

[1] Le-Klähn, D.-T., Gerike, R. and Michael Hall, C. (2014) Visitor Users vs. Non-Users of Public Transport: The Case of Munich, Germany. Journal of Destination Marketing \& Management, 3, 152-161.

[2] Jariyachamsit, S. (2015) An Investigation of Safety in Tourism: An Experience of Young Tourists in Bangkok, Thailand. Procedia-Social and Behavioral Sciences, 197, 1931-1935.

[3] Tomazzoni, E.L. and Campillo Crosdales, L.D.C. (2013) Ciclo virtuoso de satisfaccion de los turistas del evento natal luz y desarrollo turistico y socioeconomico de la ciudad de gramado (Serra Gaucha, Brasil). Estudios y Perspectivas en Turismo, 22, 630.

[4] Tello, J., Gómez, K. and López, K. (2010) Analisis del desarrollo turistico de Morelia, Michoacan. Carta Económica Regional, 22, 49.

[5] López, T., Alector, M., Orgaz, F. and Marmolejo, J. (2015) El turismo en cabo verde: Perfil y valoracion del viajero. Estudios y Perspectivas en Turismo, 24, 512.

[6] García, E.A. (2006) La satisfacción del turista en España: Un análisis de los estudios Familiatur y Frontur. Estudios turísticos, No. 168, 47-59.

[7] Sanchis, M.G. and Saura, I.G. (2012) Expectativas, satisfacción y lealtad en los servicios hoteleros. Un enfoque desde la cultura nacional. Papers de Turisme, 37-38. http://www.papersdeturisme.gva.es/ojs/index.php/Papers/article/view/87

[8] Celotto, E., Ellero, A. and Ferretti, P. (2012) Short-Medium Term Tourist Services Demand Forecasting with Rough Set Theory. Procedia Economics and Finance, 3, 62-67.

[9] Radu, A.-C. and Dobrescu, A.I. (2014) A Model for Assessing Tourists' Satisfaction of the Existing Information on Online Environment. Procedia Economics and Finance, 10, 16-22.

[10] Tsourgiannis, L., Delias, P., Polychronidou, P., Karasavvoglou, A. and Valsamidis, S. (2015) Profiling Tourists Who Have Holidays in the Region of Eastern Macedonia and Thrace in Greece. Procedia Economics and Finance, 33, 450-460.

[11] Kaiser, F. (2010) Programa Primeira Infância Melhor: Percepções do Visitador.

[12] Bodosca, Ş., Gheorghe, G. and Nistoreanu, P. (2014) Tourist Consumption Behaviour before and after the Crisis from 2008. Procedia Economics and Finance, 16, 77-87.

[13] Shaaban, K. and Khalil, R.F. (2013) Investigating the Customer Satisfaction of the Bus Service in Qatar. Procedia-Social and Behavioral Sciences, 104, 865-874.

[14] Sukiman, M.F., Omar, S.I., Muhibudin, M., Yussof, I. and Mohamed, B. (2013) Tourist Satisfaction as the Key to Destination Survival in Pahang. Procedia-Social and Behavioral Sciences, 91, 78-87. 
[15] Arasli, H. and Baradarani, S. (2014) European Tourist Perspective on Destination Satisfaction in Jordan's Industries. Procedia-Social and Behavioral Sciences, 109, 1416-1425.

[16] Wang, W.-C., Cho, W.-C. and Chen, Y.-J. (2014) Analysis of the Influence of Quantile Regression Model on Mainland Tourists' Service Satisfaction Performance. The Scientific World Journal, 2014, Article ID: 763573.

[17] Iglesias, M. (2015) Language Travel Demand: New Insights into Language Tourists' Perceptions. Procedia-Social and Behavioral Sciences, 199, 149-156.

[18] Philemon, J.R.M. (2015) Assessment of Tourists Perception and Satisfaction of Tanzania Destination. European Scientific Journal, 11, 107.

[19] Breitsohl, J. and Garrod, B. (2016) Assessing Tourists' Cognitive, Emotional and Behavioural Reactions to an Unethical Destination Incident. Tourism Management, 54, 209-220.

[20] Bigné, E. and Andreu, L. (2004) Modelo cognitivo-afectivo de la satisfacción en servicios de ocio y turismo. Cuadernos de Economia y Direccion de la Empresa, 89-120.

[21] Teo, C., Khan, N. and Rahim, F. (2014) Understanding Cultural Heritage Visitor Behavior: The Case of Melaka as World Heritage City. Procedia-Social and Behavioral Sciences, 130, 1-10.

[22] Vajčnerová, I., Žiaran, P., Ryglová, K. and Andráško, I. (2014) Quality Management of the Tourist Destination in the Context of Visitors' Satisfaction. Procedia Economics and Finance, 12, 718-724.

[23] Velázquez, B.M., Saura, I.G. and Molina, M.E.R. (2009) La formación de la lealtad y su contribución a la gestión de destinos turísticos. Cuadernos de Administración, 22, 75-98.

[24] Cronin, J.J. and Taylor, S.A. (1992) Measuring Service Quality: A Reexamination and Extension. Journal of Marketing, 56, 55-68. https://doi.org/10.2307/1252296

[25] Uribe, E.G.G., Rodríguez, J.Q. and Mercado, O.A.E. (2016) Satisfacción del usuario en la industria hotelera como factor de competitividad. Mercados y Negocios, (1665-7039), No. 22, 23-42.

[26] Herrera, C. and Arilla, J.M.P. (2013) La generación de lealtad a un destino de turismo gastronómico como factor clave en el desarrollo rural. Cuadernos aragoneses de economía, 23, 47-73.

[27] Sánchez, R. and Iniesta, Á. (2009) La estética y la diversión como factores generadores de valor en la experiencia de consumo en servicios. Revista Innovar-Marketing, 7-24.

[28] Luna, G. and Berenguer, G. (2013) Distintas etapas del uso de las fuentes de información de los turistas en Valencia, España. Estudios y perspectivas en turismo, 22, 410-424.

[29] Alén, E., Fraiz, J.A. and Rodríguez, L. (2009) Análisis de los determinantes del uso de fuentes de información previas al viaje y de las oficinas de turismo en destino. Estudios y perspectivas en turismo, 18, 546-566.

[30] Mendes, G., Biz, A. and Gândara, J.M.G. (2013) Innovación en la promoción turística en medios y redes sociales: Un estudio comparativo entre destinos turísticos. Estudios y perspectivas en turismo, 22, 102-119.

[31] Alonso, C. (2007) La publicidad Turística como agente mediático de influencia en la percepción de los territorios y otras líneas de investigación complementarias. $R e$ vista Palabra Clave, 10, 177-190.

https://dialnet.unirioja.es/descarga/articulo/2568692.pdf 
[32] Cámara, R.F.M. (2014) La señalización como determinante de la satisfacción del turista español en un territorio: El caso de Quintana Roo. CIENCIA ergo-sum, 21, 217-229.

[33] Grzinic, J. and Saftic, D. (2012) Approach to the Development of Destination Management in Croatian Tourism/Pristup razvoju destinacijskog menadzmenta u hrvatskom turizmu. Management. Journal of Contemporary Management Issues, 17, 59 .

[34] Vinh, N.Q. (2013) Destination Culture and Its Influence on Tourist Motivation and Tourist Satisfaction of Homestay Visit/Turist Motivasyonunda Mahalli Kultur ve Etkisi ve Apart Ziyaretlerinde Turist Memnuniyeti. Cankiri Karatekin Universitesi Iktisadi ve Idari Bilimler Fakultesi Dergisi, 3, 199.

[35] Ayazlar, R.A. (2015) Flow Phenomenon as a Tourist Experience in Paragliding: A Qualitative Research. Procedia Economics and Finance, 26, 792-799.

[36] Sirigunna, J. (2015) Food Safety in Thailand: A Comparison between Inbound Senior and Non-Senior Tourists. Procedia-Social and Behavioral Sciences, 197, 2115-2119.

[37] Kamata, H. and Misui, Y. (2015) The Difference of Japanese Spa Tourists Motivation in Weekends and Weekdays. Procedia-Social and Behavioral Sciences, 175, 210-218.

[38] Shemma, M. (2014) Tourist Destination: Demand-Motivating Factors in Israel's Domestic Tourism. Journal of Tourism Challenges and Trends, 7, 65.

[39] Rajaratnam, S.D., Munikrishnan, U.T., Sharif, S.P. and Nair, V. (2014) Service Quality and Previous Experience as a Moderator in Determining Tourists' Satisfaction with Rural Tourism Destinations in Malaysia: A Partial Least Squares Approach. Procedia-Social and Behavioral Sciences, 144, 203-211.

[40] Charterina, J. and Aparicio, G. (2015) A Comparison of Antecedents of Satisfaction in City Break Traveling. Revista Española de Investigación en Marketing ESIC, 19, 71-82.

[41] Ramseook-Munhurrun, P., Seebaluck, V.N. and Naidoo, P. (2015) Examining the Structural Relationships of Destination Image, Perceived Value, Tourist Satisfaction and Loyalty: Case of Mauritius. Procedia-Social and Behavioral Sciences, 175, 252-259.

[42] Kitapci, O., Akdogan, C. and Dortyol, İ.T. (2014) The Impact of Service Quality Dimensions on Patient Satisfaction, Repurchase Intentions and Word-of-Mouth Communication in the Public Healthcare Industry. Procedia-Social and Behavioral Sciences, 148, 161-169.

[43] Ragavan, N.A., Subramonian, H. and Sharif, S.P. (2014) Tourists' Perceptions of Destination Travel Attributes: An Application to International Tourists to Kuala Lumpur. Procedia-Social and Behavioral Sciences, 144, 403-411.

[44] De la Hoz, A. and Muñoz, F. (2016) Análisis de los determinantes de la predisposición a visitar un destino de turismo de bienestar: Tipologías del turista potencial. Tourism \& Management Studies, 12, 84-95. https://doi.org/10.18089/tms.2016.12210

[45] Anaya, J. and Palafox, A. (2010) El perfil del turista internacional de Cozumel a partir de la construcción de su capital simbólico. Revista División de Desarrollo Sustentable, 171-185.

[46] Igúzquiza, V.D. de R. (2009) Análisis de datos de encuestas: Desarrollo de una investigación completa utilizando SPSS. Editorial UOC.

[47] Torres, C.A.B. (2006) Metodología de la investigación: Para administración, eco- 
nomía, humanidades y ciencias sociales. Pearson Educación.

[48] Saldana, J.P.C. and Urcia, L.A.A.D.L.G. (2010) Metodologia de La Investigacion Cientifica En Postgrado. Lulu.com.

[49] Supo, J. (2013) Cómo validar un instrumento. Perú. http://www.validaciondeinstrumentos.com

[50] Ferrer, G.G. (2016) Investigación commercial. 4th Edition, ESIC Editorial.

[51] Alarcón, V.F. (2010) Desarrollo de sistemas de información: Una metodología basada en el modelado. Univ. Politéc. de Catalunya.

[52] Horsten, L.R., Beltrán, C.A. and Moreno, M.P. (2013) Validación de un instrumento de evaluación del desempeño en el trabajo. Revista Iberoamericana de Psicología: Ciencia y Tecnología, 6, 25-32.

[53] Ringle, C.M., Wende, S. and Becker, J.M. (2015) SmartPLS. SmartPLS GmbH, Boenningstedt.

[54] Carmines, E.G. and Zeller, R.A. (1979) Reliability and Validity Assessment. SAGE Publications. https://doi.org/10.4135/9781412985642

[55] González, J. (2013) Estudios sobre innovación tecnológica en España. Editorial UNED.

[56] Falk, R.F. and Miller, N.B. (1992) A Primer for Soft Modeling. University of Akron Press.

[57] Fornell, C. and Larcker, D.F. (1981) Evaluating Structural Equation Models with Unobservable Variables and Measurement Error. Journal of Marketing Research, 18, 39-50. https://doi.org/10.2307/3151312

[58] Chin, W.W. (1998) The Partial Least Squares Approach for Structural Equation Modeling. In: Modern Methods for Business Research, Lawrence Erlbaum Associates Publishers, Mahwah, 295-336.

[59] Moreno, R.R. and Molina, C.M. (2012) Marketing Público: Investigación, aplicaciones y estrategia. ESIC Editorial.

[60] Soto, C.C. (2014) Organización de viajes nacionales e internacionales. Ediciones Paraninfo, S.A.

[61] Zulaica, A.R. (2014) Planificación, programación y operación de viajes combinados. Ediciones Paraninfo, S.A.

[62] Bigné, J.E., Font, X. and Andreu, L. (2010) Marketing de destinos turísticos: Análisis y estrategias de desarrollo. ESIC Editorial.

[63] Borja, M.Á.G., Jiménez, J.A.M. and Sevilla, C.S. (2005) Gestión del turismo cultural y de ciudad. Univ de Castilla La Mancha.

[64] Pinilla, J.M.C. and González, A.B. (2014) Estrategias de marketing sectorial. ESIC Editorial.

[65] García, M.S., Roig, J.G. and Royo, A.G. (1998) Frenos al crecimiento del mercado ecológico? El precio o la actitud hacia el medio ambiente. Revista Española de Investigación de Marketing (ESIC), 103-116.

[66] Britos, S. (2002) La alimentación en tiempos de crisis. Intervenciones so-ciales en relación con los precios de alimentos. Archivos Argentinos de Pediatria, 100, 402.

[67] Mitre, M. (2006) La producción e intermediación turística en el sector de las agencias de viajes. Universidad de Oviedo.

[68] Berné Manero, C., García-González, M., García-Uceda, M.E. and Múgica Grijalba, J.M. (2013) Identificación y análisis de los criterios de cambios del sistema de distribución turístico asociados al uso intensivo de las tecnologías de la información y 
de la comunicación. Investigaciones Europeas de Dirección y Economía de la Empresa, 19, 90-101.

[69] Berné Manero, C., García Gonzalez, M., García-Uceda, M.E. and Múgica Grijalba, J.M. (2012) MOdelización de los cambios en el sistema de distribución del sector turístico debidos a la incorporación de las tecnologías. Cuadernos de Economia y Direccion de la Empresa, 15, 117-129.

[70] Venacio, L. (2004) Globalización, Desarrollo Local y Sociedad Civil. Juan Carlos Martínez Coll, Italia.

[71] Novás, N.C. (2010) Promoción Y Venta de Servicios Turísticos. Ideaspropias Editorial S.L.

[72] Lee, C.-C. and Chen, C.-J. (2013) The Relationship between Employee Commitment and Job Attitude and Its Effect on Service Quality in the Tourism Industry. American Journal of Industrial and Business Management, 3, 196-208. https://doi.org/10.4236/ajibm.2013.32025

[73] Millet, O.F. (2011) La imagen de un destino turístico como herramienta de marketing. Grupo EUMEDNET. http://dialnet.unirioja.es/servlet/libro?codigo=482050

[74] Aurelien, D. and Zhao, J. (2014) Determinants of Destination Management System (DMS) and Tourism Industry Assessment of Madagascar. American Journal of Industrial and Business Management, 4, 790-798. https://doi.org/10.4236/ajibm.2014.412085

[75] Aurélien, D. and Desiré, R.J. (2014) An Evaluation of Destination Management Systems in Madagascar with Aspect of Tourism Sector. American Journal of Industrial and Business Management, 4, 514-522. https://doi.org/10.4236/ajibm.2014.49057

[76] Xu, R. and Wang, J. (2016) A Study of Tourist Loyalty Driving Factors from Employee Satisfaction Perspective. American Journal of Industrial and Business Management, 6, 1122-1132. https://doi.org/10.4236/ajibm.2016.612105

Submit or recommend next manuscript to SCIRP and we will provide best service for you:

Accepting pre-submission inquiries through Email, Facebook, LinkedIn, Twitter, etc. A wide selection of journals (inclusive of 9 subjects, more than 200 journals)

Providing 24-hour high-quality service

User-friendly online submission system

Fair and swift peer-review system

Efficient typesetting and proofreading procedure

Display of the result of downloads and visits, as well as the number of cited articles

Maximum dissemination of your research work

Submit your manuscript at: http://papersubmission.scirp.org/

Or contact jssm@scirp.org 